\title{
Analysis of the effects of adding pyroclastic rock to red mud for the production of a baked building material in terms of its resistance to frost actions
}

\author{
Mustafa Dereli ${ }^{1}$ (D) $\cdot$ Mustafa Tosun ${ }^{1}$
}

Received: 12 March 2020 / Accepted: 31 August 2020 / Published online: 5 September 2020

(c) Springer Nature Switzerland AG 2020

\begin{abstract}
In the aluminum sector, approximately 130 million tons of waste red mud was produced in the last year. Such a high amount of wastes causes their storage areas to become a threat to the environment. Numerous studies have been conducted in the literature to eliminate this environmental threat. However, it is observed that these studies are mostly conducted on only a part of the waste, and there are few studies on the whole consumption of waste. Due to the said lack in the literature, it is thought that this waste can be utilized as a baked building material and consumed systematically. However, according to the literature and previous studies, it is observed that the use of the waste alone will not produce a quality building material. Therefore, otiose pyroclastic rocks were included within the scope of the study to be used together with the waste material. Accordingly, micronized pyroclastic rocks obtained from different regions were added to red mud at the proportions of $10,20,30,40$, and $50 \%$ by weight. Bentonite of $3 \%$ was added to mixtures to prevent capillary cracks. As a result of the preliminary experiments conducted on the baked building material samples obtained with the above-mentioned mixture ratios, two mixture types from each region with the highest compressive strength were selected. Physical and mechanical experiments were conducted on the samples to determine the resistance to frost actions - as an outer ambient condition with the most destructive effect-of the baked building materials (especially brick, etc. with the widest area of usage in outer walls and surface cover materials such as ceramic, clinker pavement, etc.) which will be obtained with these mixtures. As a result of the study, the optimum mixture type was determined to be the sample formed by adding $10 \%$ volcanic tuff around campus to red mud and baking it at a temperature of $1050^{\circ} \mathrm{C}$. Furthermore, different mixture types formed by adding the micronized pyroclastic material from other regions could reach sufficient values in terms of both compressive strength and frost actions. According to the results of the study, this material will fulfill the need for raw material as a building material resistant to frost actions and used in outer masonry. In this study, a process was obtained to eliminate a potential environmental problem, and a contemporary building material intended to be used as a sustainable building material was produced.
\end{abstract}

Keywords Red mud $\cdot$ Pyroclastic rock $\cdot$ Baked building material $\cdot$ Resistance to frost

\section{Introduction}

For the production of 2 tons of alumina, 4 tons of bauxite is treated by the Bayer process, and as a result, about 1 ton of aluminum metal is obtained [1]. During this production,
130 million tons of waste sludge is produced for the annual production of 65 million tons of aluminum in the world [1]. This waste with a high alkaline $(\mathrm{pH}=10)$ content is known as red mud [2]. Regarding the area where waste is stored, it is known that not only the size of the place it occupies is

$\square$ Mustafa Dereli, mdereli@ktun.edu.tr| ${ }^{1}$ Faculty of Architecture and Design, Department of Architecture, Konya Technical University, Konya, Turkey. 
big, but also it causes a severe environmental problem. As a result of any problem that may occur in tailings ponds, red mud will spread to the environment and cause irreparable damage. This potential environmental disaster will cause severe problems, as was observed in wastes that were spread to many European countries as a result of the pond accident (set collapse) in Ajka, Hungary $[3,4]$. Therefore, waste should be consumed by being used systematically $[5,6]$. High iron content, the presence of alkalis, and its very fine-grained structure cause the application areas to be limited. Studies were carried out on bricks [7-9], ceramic $[10,11]$, cement $[12,13]$, glass (ceramic glazes) [14], and metal extraction [15] to develop more products. Moreover, studies were conducted on the opportunity of its use in geopolymer manufacturing [16-18] and other technology [19-21] fields. However, there is no product actualized by finding an industrial area of use based on the studies. Thus, it was deemed appropriate to obtain artificial clay by adding to this waste and to conduct a study on it as a baked building material instead of adding sludge to other products. For this reason, it was decided to add a pyroclastic rock to increase the clay property of this material. The mentioned pyroclastic rocks are quite common in the region, which constitutes the subject of this study. However, in this study, inactive pyroclastic fields were preferred. Pyroclastic materials used in the study are known as volcanic tuffs and basaltic slag (pumice). Although volcanic tuffs, which are used in many sectors, were used in the cement and concrete industry [22-25], some studies were also carried out in the ceramic industry [26, 27]. The inactive pyroclastic fields that are the subject of the present study were started to be processed in line with these studies. However, these fields were abandoned when their economic performance was not sufficient. Therefore, red mud waste and micronized materials obtained from inert pyroclastic fields were used together in the study.

The usage of the baked building material obtained with different mixing ratios in the outer shell can only be possible with the formation of its resistance to external effects. The frost action has the most damaging effect among the external effects. Thus, in this study, the effects of micronized pyroclastic rocks at different mixing ratios and baking temperatures were discussed in terms of resistance to frost actions in the baked building material.

\section{Materials and methods}

\subsection{Red mud (RM)}

In the study, red mud, which was released as a waste into nature (tailings ponds) from Konya Seydişehir ETi aluminum factory, was used. The materials used in the study were obtained from the given coordinates $37^{\circ} 27^{\prime} 39.09^{\prime \prime}$ $\mathrm{N}$ latitude, $31^{\circ} 48^{\prime} 43.00^{\prime \prime}$ E longitude. According to the study, it was determined that 3 million tons of the material accumulated in this tailings pond between 1973 and 1996.

\subsection{Pyroclastic rock}

Since volcanic-origin rocks are formed as a result of different events occurring during volcanic mobility and have many types, a common naming has become a requirement when defining these rocks. Therefore, the general naming of volcanic materials (volcanic tuff and basaltic slag) was used as "pyroclastic rock", also known as "pyroclast", in the study. Due to the differences in the volcanic tuff and basaltic pumice materials used in the study, the pyroclastic materials used in the study were discussed below under subheadings according to the region from which they were provided.

\subsubsection{Volcanic tuff around Selahattin village (SVT)}

The first item of the volcanic materials used in the study was obtained from the inactive and abandoned tuff area around Selahaddin village located between Derbent district and Konya province. The coordinates of the sample site situated in the inactive tuff area are $38^{\circ} 1^{\prime} 7.94^{\prime \prime}$ N latitude and $32^{\circ} 8^{\prime} 40.55^{\prime \prime}$ E longitude. The color of the material taken from the region is white.

\subsubsection{Volcanic tuff around campus (CT)}

The tuff area, which is the second among the volcanic materials, was also left inactive and is located in the Selcuklu district of Konya, near Selcuk University Alaeddin Keykubat Campus. The samples were taken from the inactive tuff area at $38^{\circ} 2^{\prime} 8.96^{\prime \prime} \mathrm{N}$ latitude, $32^{\circ} 28^{\prime} 13.07^{\prime \prime}$ E longitude coordinates to be used in the study. The color of the tuff taken from the region is gray.

\subsubsection{Karapınar region basaltic slag (basaltic pumice)}

Basaltic slag samples were taken around the Karapinar district of Konya province. According to the coordinate system, it is located between $37^{\circ} 40^{\prime} 18.31^{\prime \prime} \mathrm{N}$ latitude and $33^{\circ}$ $41^{\prime} 46.24^{\prime \prime}$ E longitude. Since there are two different colors of layers in the same region, the materials taken here were divided into the subheadings given below according to the color status.

2.2.3.1 Karapınar region red-colored slag (KRS) The characteristic color of the slag in the region is dark gray-black. However, due to the oxidized iron content, red-colored layers were formed in places. In the study, red and black- 
colored slags were considered as different materials, and red-colored slags were examined as mentioned under this title.

2.2.3.2 Karapınar region black-colored slag (KBS) The characteristic color of the slags in the region is dark gray and black. In the study, black-colored slags, which are also abbreviated under this title, were used as materials.

\subsection{Properties of raw materials}

Preliminary studies were conducted for the materials. These studies are discussed below with their results.

\subsubsection{Chemical analysis (XRF)}

The chemical analysis data in Table 1 for red mud are based on the literature [28]. The chemical analysis of pyroclastic rocks was performed in the R\&D Laboratory of Kütahya Ceramic Factory. For this analysis, a Spectro X-LAB 2000 [400-W Rh endwindow tube and $\mathrm{Si}(\mathrm{Li})$ detector with a resolution of $148 \mathrm{eV}$ (1000 cps Mn Ka)] device was used, and the oxide values were determined by a method appropriate for the TS EN 15309 standard, named as "Characterization of waste and soil-determination of elemental composition by X-ray fluorescence" [29].

\subsubsection{Particle density}

The determination of particle density [30] was performed by the pycnometer method by fluid displacement specified in the standard (TS EN ISO 17892-3). The fluid pycnometer method is based on the main principle of determining the difference between the fluid volume needed for filling the pycnometer with and without a sample in it. The

Table 1 Chemical analysis of red mud and pyroclastic rocks

\begin{tabular}{lccccc}
\hline Component & RM (\%) & SVT (\%) & CT (\%) & KRS (\%) & KBS (\%) \\
\hline $\mathrm{Na}_{2} \mathrm{O}$ & 5.79 & 3.96 & 0.88 & 3.08 & 2.1 \\
$\mathrm{MgO}$ & 0.26 & 1.58 & 2.04 & 6.15 & 6.39 \\
$\mathrm{Al}_{2} \mathrm{O}_{3}$ & 21.08 & 14.79 & 15.16 & 15.31 & 17.13 \\
$\mathrm{SiO}_{2}$ & 15.58 & 68.8 & 67.39 & 47.2 & 51.23 \\
$\mathrm{P}_{2} \mathrm{O}_{5}$ & 0.04 & 0.05 & 0.15 & 0.22 & 0.27 \\
$\mathrm{SO}_{3}$ & 0.56 & 0.07 & 0.06 & 0.04 & 0.03 \\
$\mathrm{~K}_{2} \mathrm{O}$ & 0.61 & 4.57 & 2.93 & 0.78 & 0.07 \\
$\mathrm{CaO}$ & 2.71 & 5.12 & 3.8 & 9.94 & 10.32 \\
$\mathrm{TiO}_{2}$ & 4.62 & 0.17 & 0.43 & 0.98 & 1.03 \\
$\mathrm{MnO}$ & 0.03 & 0.08 & 0.06 & 0.13 & 0.15 \\
$\mathrm{Fe}_{2} \mathrm{O}_{3}$ & 30.37 & 1.53 & 4.27 & 9.64 & 9.88 \\
Loss on ignition (\%) & 15.66 & 17.54 & 15.50 & 1.06 & 6.35 \\
\hline
\end{tabular}

density of solid grains is measured from the dry weight of the ground grains and volume difference.

\subsubsection{Liquid limit value}

The liquid limit value was determined by the experiment performed in accordance with the method described in the standard named "Methods of Testing Soils for Civil Engineering Purposes in the Laboratory" [31]. Accordingly, three different analyses were conducted, and a graph was drawn for the liquid limit value.

\subsubsection{Plastic limit value}

The plastic limit value was determined by the experiment performed in accordance with the method described in the standard named "Methods of Testing Soils for Civil Engineering Purposes in the Laboratory" [31]. The plastic limit experiment was repeated twice.

\subsection{Production of experiment samples}

The pulverizing process was carried out to micronize pyroclastic rocks from the material to be mixed. The sample production steps with the materials to be mixed were conducted in the following order, and the obtained methodological results were explained in the experiment results.

\subsubsection{Pulverizing}

Pyroclastic rocks were pulverized to pass through a 100-micron sieve in a laboratory-type ball-rod mill and steel balls produced by Ünal Engineering and Machine Industry. The samples were subjected to drying in a stove under $105^{\circ} \mathrm{C}$ until they reached the constant mass. Accordingly, the constant mass means weighing the sample dried in a stove at intervals of $24 \mathrm{~h}$ and not having a difference bigger than $0.2 \%$ between the last two weighings.

\subsubsection{Mixing and Remolding}

In the production of samples to be used in the experiments, the production of samples was carried out by adding pyroclastic rock at different percentages to pure red mud and the main raw material red mud. The primary purpose is to use red mud at high rates and to make it possible to consume waste in this way. Therefore, it was decided to test the pure red mud for determining the potential of baked building materials. Thanks to the said method, using this material from its natural environment will provide economic gains. The method of "using pure red mud as it is" was chosen as the first sample type to learn the behavior of red mud against baking. For other 
mixtures, the micronized pyroclastic rock was added as $10 \%, 20 \%, 30 \%, 40 \%$, and $50 \%$ by weight in relation to red mud. The "percentage by weight in dry material" method was selected for the amount of material to be used in mixtures. With these additions, it was aimed to detect changes in different baking temperatures, physical properties, or mechanical properties and, in this way, to achieve an optimum mixture ratio in the production of a material with high mechanical strength.

\subsubsection{Molding}

Since the waste materials to be used in the production of experiment samples have a clay-like structure used in baked building materials, molding forms used in this field was targeted as a method in sample production.

In the compressive strength experiment to be performed on samples, it was deemed appropriate to choose a standard method suitable for similar sample types. For laboratory-type samples, $5 \times 5 \times 5 \mathrm{~cm}$ cube samples specified in the ASTM C109 standard were observed to be simi$\operatorname{lar}[32]$.

\subsubsection{Baking}

Red mud was baked in the pure form at different temperatures prior to the study. As a result of the control by hand at a temperature of $1100{ }^{\circ} \mathrm{C}$, it was observed that the pure red mud was baked. Therefore, in this study, it was thought that the pyroclastic rocks added to red mud could be baked at lower temperatures. Hence, the baking process with decreasing temperatures such as 1050, 1000, and $950^{\circ} \mathrm{C}$ was selected.

\subsection{Selection of sample types for experiments}

Since there are a lot of different mixture types and baking temperatures, samples to be used within the scope of this study were selected according to the results of preliminary experiments to narrow the scope. The information about the sample selection is given in the experiment results.

\subsection{Experiments on samples}

The experiments given below were conducted to reveal the physical and mechanical properties of samples.

\subsubsection{Net dry density}

To determine the net dry density values, the method in accordance with the TS EN 772-13 standard was followed, and the calculations were made [33]. Accordingly, the net volumes of the twelve samples, which were smoothed to $50 \times 50 \times 50 \mathrm{~mm}$ by abrading their surfaces, were calculated for each type of mixture and made ready for the experiment. The lowest and highest results were obtained for the net dry density values obtained from the twelve samples for each type, and the arithmetic mean of the other values was calculated. The following formula was used in measurements (2.1):

$\rho_{n, u}=\frac{m_{d r y, u}}{V_{n, u}}$

$\rho_{n, u}=$ net dry density $\left(\mathrm{kg} / \mathrm{m}^{3}\right), m_{d r y, u}=\operatorname{dry}$ mass $(\mathrm{kg})$, $V_{n, u}=$ volume $\left(\mathrm{m}^{3}\right)$.

\subsubsection{True density}

True density calculations were made according to the pycnometer method specified in the standard named "Natural stone test methods-determination of real density and apparent density and of total and open porosity" [34]. The true density experiment was performed with two different pycnometers for each type of mixture, and the arithmetic mean of the results was calculated. The following formula was used in measurements (2.2):

$\rho_{r}=\frac{m_{e}}{m_{2}+m_{e}-m_{1}} \times \rho_{r h}$

$\rho_{r}=$ true density $\left(\mathrm{kg} / \mathrm{m}^{3}\right), m_{e}=$ pulverized dry sample mass $(\mathrm{kg}), m_{1}=$ pycnometer mass with sample $(\mathrm{kg}), m_{2}=$ pycnometer mass without sample $(\mathrm{kg}), \rho_{r h}=$ density of water at $20^{\circ} \mathrm{C}\left(998 \mathrm{~kg} / \mathrm{m}^{3}\right)$.

\subsubsection{Water absorption under normal conditions}

The water absorption experiment on the samples was conducted in two groups as water absorption by mass and water absorption by volume.

2.6.3.1 Water absorption by mass The water absorption experiment by mass was carried out in accordance with the method specified in the standards named "Clay Masonry Units-Properties" and "Natural Building BlocksInspection and Experiment Methods" $[35,36]$. The lowest and highest results were calculated for the water absorption values by mass obtained from the twelve samples used for all different types, and the arithmetic mean of the other values was calculated. The water imbibition value in mass was measured using the following formula (2.3). The samples were dried until they reached the constant weight before the weighing to determine the dry mass of the samples. 
$W_{m}=\frac{m_{w}-m_{d}}{m_{d}} \times 100$

$\mathrm{W}_{\mathrm{m}}=$ water absorption by mass (\%), $m_{w}=$ waterlogged sample mass $(\mathrm{g}), m_{d}=$ sample mass dried until constant weight (g).

2.6.3.2 Water absorption by volume The water absorption experiment by volume includes the methods used in the water absorption experiment by mass. Moreover, the weight of the waterlogged samples in water must be calculated. Therefore, twelve experiment samples were weighed on the Archimedes scale. The results of the experiment were obtained using the method specified in the standard [36]. The lowest and highest results were calculated for the water absorption values by volume obtained from the twelve samples for each type, and the arithmetic mean of the other values was calculated. The water imbibition value in volume was calculated using the following formula (2.4):

$W_{v}=\frac{m_{w}-m_{d}}{m_{w-m_{w w}}} \times 100$

$W_{v}=$ water absorption by volume (\%), $m_{w}=$ waterlogged sample mass $(\mathrm{g}), m_{d}=$ sample mass dried until constant weight $(\mathrm{g}), m_{w w}=$ the mass of waterlogged sample in water (g).

\subsubsection{Apparent porosity (artificial porosity)}

The apparent porosity is the same as the water absorption rate by volume, and the calculations made under the relevant heading are also valid for this section. The calculations can also be made in a different way using the net dry density and the water absorption rate by mass. Accordingly, the apparent porosity values were calculated using the TS 699 standard [36]. In this way, it was tested whether there was any deviation in the method by finding the opportunity to compare the water absorption rate by volume and the apparent porosity ratio. Accordingly, the apparent porosity values were calculated using the following formula (2.5):

$P_{g}=\rho_{n, u} \times W_{m}$

$P_{g}=$ apparent porosity (\%), $\rho_{n, u}=$ net dry density $\left(\mathrm{g} / \mathrm{cm}^{3}\right)$, $W_{m}=$ water absorption by mass (\%).

\subsubsection{Compactness ratio}

The compactness ratio of materials is known as the ratio of unit volume weight to specific gravity. Accordingly, the ratio of the net dry density to the true density of the samples was calculated as a percentage value using the following formula (2.6):

$C=\frac{\rho_{n, u}}{\rho_{r}} \times 100$

$C=$ compactness ratio $(\%), \rho_{n, u}=$ net dry density $\left(\mathrm{kg} / \mathrm{m}^{3}\right)$, $\rho_{r}=$ true density $\left(\mathrm{kg} / \mathrm{m}^{3}\right)$.

\subsubsection{Degree of porosity}

The sum of porosity and compactness ratio constitutes the whole of the materials. The porosity values were calculated using the following formula (2.7):

$P=(1-C) \times 100$

$P=$ degree of porosity (\%), $C=$ compactness ratio (\%).

\subsubsection{Compressive strength}

The experiment was carried out according to the methods specified in the standards named "Methods of test for masonry units - part 1: determination of compressive strength" and "Standard Test Methods for Sampling and Testing Brick and Structural Clay Tile" [37, 38].

Seven samples of $50 \times 50 \times 50 \mathrm{~mm}$ for each type were developed for cement sample experiments, and compressive strength values were determined using a device with $50 \times 50 \mathrm{~mm}$ heads. The standard loading speed of the device was selected as $0.60 \mathrm{~N} / \mathrm{mm}^{2}$. The lowest and highest values of the seven samples broken for compressive strength values were obtained from the average calculations as the deviation value. Compressive strength values were calculated using the following formula (2.8):

$R_{c}=\frac{F_{c}}{A}$

$R_{\mathrm{c}}=$ compressive strength $\left(\mathrm{N} / \mathrm{mm}^{2}\right), F_{c}=$ force $(\mathrm{N}), A=$ surface area of compressive strength $\left(\mathrm{mm}^{2}\right)$.

\subsubsection{Experiment for resistance to frost action}

The frost-decomposition experiment was carried out using the methods described in the TS EN 771-1, TS EN 539-2, and ASTM C67-11 standards [35, 38, 39]. The deep freezer set to $-22{ }^{\circ} \mathrm{C}$ was used in the experiment.

First of all, three samples of each type to be subjected to the experiment (D1, D2, and D3 were added to the samples to be used in frost experiments while naming the samples) were dried in the oven until they reached the constant mass. The samples taken out of the oven were cooled with a desiccator and weighed on a balance 
with a sensitivity of $0.01 \mathrm{~g}$ and recorded $\left(\mathrm{G}_{0}\right)$. The samples were then saturated with water by the method used in the water absorption test. The temperature of the freezer was set to $-22{ }^{\circ} \mathrm{C}$. It was assumed that the samples were frozen at least $8 \mathrm{~h}$ after being placed in the freezer. At the end of freezing, the samples were removed from the freezer and left to decompose in the water pool at ambient temperature. The decomposition time was determined to be at least $4 \mathrm{~h}$. This frost and decomposition process is called the "cycle". It is said that there should be at least 24 cycles in the standards related to frost-decomposition processes on building materials. Therefore, it was decided to conduct 25 cycles.

As a result of the frost action, observations were made about how damage occurred in the samples or that they completed the process without any signs of damage. The samples, which did not disperse at the end of the experiment, were dried in the oven, cooled in the desiccator, weighed and recorded. The frost loss on the samples was calculated [40] according to the formula (2.9) presented below:

$D_{k}=\frac{G_{0}-G_{k d o n}}{G_{k d o n}} \times 100$

$D_{k}=$ frost loss (\%), $G_{0}=$ dry weight before experiment $(\mathrm{g})$, $G_{k d o n}=$ dry weight after experiment $(\mathrm{g})$.

The pressure resistance experiment was also performed to determine whether there was a difference in the mechanical strength of the samples of which frost loss was calculated. Accordingly, the samples dried to a constant mass were cooled in the desiccator, and the pressure experiment was applied. The average values of the compressive strength under normal conditions were compared with the compressive strength average values at the end of the frost-decomposition process.

The relation between the compressive strength at the end of the frost-decomposition experiment and the compressive strength under normal conditions was calculated using the formula (2.10) presented below [40]:

$\Delta f=\frac{f_{b}-f d_{b}}{f b} \times 100$

$\Delta f=$ decrease in compressive strength (\%), $f_{b}=$ normal sample compressive strength $\left(\mathrm{N} / \mathrm{mm}^{2}\right), f d_{b}=$ compressive strength after frost-decomposition $\left(\mathrm{N} / \mathrm{mm}^{2}\right)$.

\section{Experiment results and evaluation}

\subsection{Properties of raw materials}

\subsubsection{Chemical analysis (XRF)}

The results obtained according to the analysis are given in Table 1.

According to the results of the analysis of red mud, the fact that it contains $30.37 \% \mathrm{Fe}_{2} \mathrm{O}_{3}$ (hematite) shows that it has rich iron content. Furthermore, it can be said that it gives the red color to the waste due to its oxidized high iron content. Due to this color, it was considered that it could be used in brick, tile, and ceramic industries.

\subsubsection{Particle density}

The operations showing the calculations made with the data obtained at the end of the particle density experiments are given in Table 2.

\subsubsection{Liquid limit value}

Accordingly, three different analyses were made, and a graph was drawn for the liquid limit value. As is seen in Table 2, other raw materials except for red mud did not provide the liquid limit value.

\subsubsection{Plastic limit value}

The data obtained at the end of the experiment are given in Table 2.

In the study conducted by Malayoğlu and Akar [41], the materials with plastic properties between 10 and $30 \%$ were classified as non-clay materials and ordinary clays. Malayoğlu and Akar stated that clays with kaolin and montmorillonite content had a plastic property between 30 and $65 \%$, while bentonite-containing clays had a plastic property of $80 \%$ and above. Accordingly, it can be stated that red mud is a material that does not provide sufficient plastic property, depending on the plastic limit experiment result.

Table 2 Particle density, liquid limit, and plastic limit values of raw materials

\begin{tabular}{llllll}
\hline & RM & SVT & CT & KRS & KBS \\
\hline $\begin{array}{l}\text { Particle density (g/ } \\
\mathrm{cm}^{3} \text { ) }\end{array}$ & 2.93 & 2.58 & 2.64 & 2.93 & 2.72 \\
Liquid limit (\%) & 41.5 & No value & No value & No value & No value \\
Plastic limit (\%) & 28.4 & No value & No value & No value & No value \\
\hline
\end{tabular}




\subsection{Production of experiment samples}

The results obtained during the production of experiment samples are presented in the following section.

\subsubsection{Pulverizing}

While the volcanic tuff group was oven-dried at $105^{\circ} \mathrm{C}$ and reached its constant mass in $48 \mathrm{~h}$, this temperature was not sufficient for the basaltic slag group. Then, the pulverizing process was conducted after the calcining process carried out for $24 \mathrm{~h}$ at $300-400^{\circ} \mathrm{C}$ for crystal water.

\subsubsection{Mixing and remolding}

Hundreds of samples were produced to be used in experiments. Such layers as capillary cracks were observed on the surfaces of the first produced samples. Due to the insufficient plastic properties of the sample mixtures, it was concluded that they were effective in these layers. Therefore, it was decided to add an additive that would be used in very small amounts and would provide plastic properties to the mixture. To remove the observed layers, new samples were produced by adding $3 \%$ and $5 \%$ of bentonite. The KAR-CVL (construction bentonite) [42-45] material produced by Karakaya Bentonite company was used. Any visible difference was not observed after adding bentonite. Therefore, a ratio of $3 \%$ was chosen as the additive amount, and this amount was included in the mixture ratio of all the samples to be produced next time. A sample calculation is given below to be used in determining the amount of material to be mixed.

3.2.2.1 Mixture calculation sample The water content analysis was performed on $1000 \mathrm{~g}$ red mud as it was taken from the waste environment. According to the analysis, if the water content in the red mud is calculated as $40 \%$, the amount of dry material will be $600 \mathrm{~g}$ accordingly. If it is necessary to calculate in a way to add $10 \%$ pyroclastic, $600 \mathrm{~g}$ dry material is counted for $90 \%$, and $67 \mathrm{~g}$ material amount is calculated for $10 \%$. The total amount of dry material entered into the mixture is $667 \mathrm{~g}$. In line with this result, since 3\% bentonite will be added, the calculation is made using the same proportion method. Accordingly, if $667 \mathrm{~g}$ of dry material is $97 \%$, the additional amount of $3 \%$ bentonite is calculated as $21 \mathrm{~g}$ (Table 3 ).

\subsubsection{Molding}

Plaster molds with an inner gap of $5 \times 5 \times 5 \mathrm{~cm}$ cube were successful within the scope of the study. However, arrangements in dimensions became necessary because of the drying dwindling proportion in plaster molds. Accordingly, plaster molds were made to produce samples of these sizes. Using these molds, the final shape was given to the samples before baking.

\subsubsection{Baking}

Due to the different content of the samples, preliminary experiments were conducted for optimum temperature values. Firstly, the minimum temperature value was determined for baking red mud in its pure form. The prepared samples were baked at 1000,1050 , and $1100^{\circ} \mathrm{C}$. In the examination through observation, the pure form of red mud showed the feature of a baked material at the border of $1100^{\circ} \mathrm{C}$. The value of $1100^{\circ} \mathrm{C}$ was accepted as the upper limit value, and one sample from each mixture ratio was baked at this temperature value. As the rate of the addition of pyroclastic rock increased at this temperature, a high rate of shrinkage occurred in the volume. Accordingly, it was concluded that it is possible to bake at lower temperatures. Therefore, the baking process was carried out at different temperatures, such as 1050,1000 , and $930^{\circ} \mathrm{C}$, to determine the optimum temperature and optimum mixing ratio of the samples to be used in the preliminary experiments. A temperature of $930^{\circ} \mathrm{C}$ was specifically chosen here. The samples were intended to be cooked at $950^{\circ} \mathrm{C}$, but since the ovens in the laboratory did not have a suitable value for this temperature setting, the $930^{\circ} \mathrm{C}$ temperature setting was chosen as the closest temperature.

\subsection{Selection of sample types for experiments}

Hundreds of samples were prepared using the method described above. Due to high volume losses at the end of the baking of pyroclastic additions micronized in $40 \%$ and $50 \%$ of the samples, the samples at these rates were excluded from the study. Furthermore, the CT group dispersed at the rates of $20 \%$ and $30 \%$ of additional baking. Therefore, this group was excluded from the scope of the study. Among the remaining samples, two of the groups with different mixture types were selected, each of which

Table 3 Mixture calculation according to the addition of $10 \%$ pyroclastic rock

\begin{tabular}{lllllll}
\hline Watery red mud & Dry material & Water amount & $90 \%$ dry red mud & $10 \%$ pyroclastic addition & Total dry material & $3 \%$ Bentonite addition \\
\hline $1000 \mathrm{~g}$ & $600 \mathrm{~g}$ & $400 \mathrm{~g}$ & $600 \mathrm{~g}$ & $67 \mathrm{~g}$ & $667 \mathrm{~g}$ & $21 \mathrm{~g}$ \\
\hline
\end{tabular}


had the best compressive strength results. Accordingly, the samples presented in Table 4 were used in the study.

\subsection{Experiments on samples}

The results of the net dry density, true density, water absorption, apparent porosity, compactness, porosity ratio, and compressive strength experiments conducted on samples are given in Table 5.

According to TS 704, the arithmetic mean of the water absorption values of blend brick samples should not be higher than $18 \%$ [46]. The water absorption values of the material to be used as brick are especially important because it can absorb the water of the adhesive mortar and surface coating plaster to be used for building. In applications, wetting the brick wall surfaces may partially solve this problem. According to the results obtained in the study, it was concluded that the water absorption values of the CT group samples might be appropriate, while the other types could be used as a brick-like building material by using water-repellent additives. It is possible to say that it can be used as a ceramic coating in places where there is no situation like water absorption (for example, wall covering).

Özdemir gave the porosity value of some materials in his study [47]. According to his study, the ratios were as follows: aerated concrete $74 \%$, pumice concrete $61.8 \%$, concrete $19 \%$, andesitic tuff $8.7 \%$, limestone $3.1 \%$, and granite $0.9 \%$. When these materials were compared with the samples used in the study, it was observed that the results were close to the value of pumice concrete. According to the results, it is possible to say that the samples have a very porous structure.

When the compressive strength results of the samples were examined, it was observed that they had higher values than the compressive strength of low-density brick given in TS EN 772-1 [37] and that the samples named KBS 201050 gave results close to high-density brick values. According to these results, it was concluded that it was possible to manufacture bricks that would be exposed to pressure from all types of mixtures and to produce coating materials such as ceramic, clinker, etc. that were not related to compressive strength.

Table 4 Mixing ratios and baking temperatures of the samples used in the experiments

\begin{tabular}{lc}
\hline Sample region, mixing ratio, baking temperature & Abbreviation \\
\hline Selahattin Village Tuff (SVT), $30 \%$ mixing ratio, $930{ }^{\circ} \mathrm{C}$ baking temperature & $\mathrm{SVT} 30930$ \\
Selahattin Village Tuff (SVT), $30 \%$ mixing ratio, $1050{ }^{\circ} \mathrm{C}$ baking temperature & $\mathrm{SVT} 301050$ \\
Volcanic Tuff Around Campus (CT), $10 \%$ mixing ratio, $1000^{\circ} \mathrm{C}$ baking temperature & $\mathrm{CT} 101000$ \\
Volcanic Tuff Around Campus (CT), $10 \%$ mixing ratio, $1050{ }^{\circ} \mathrm{C}$ baking temperature & $\mathrm{CT} 101050$ \\
Karapınar Region Red-Colored Slag (KRS), $20 \%$ mixing ratio, $930{ }^{\circ} \mathrm{C}$ baking temperature & $\mathrm{KRS} 20930$ \\
Karapınar Region Red-Colored Slag (KRS), $30 \%$ mixing ratio, $1050{ }^{\circ} \mathrm{C}$ baking temperature & $\mathrm{KRS} 301050$ \\
Karapınar Region Black-Colored Slag (KBS), $20 \%$ mixing ratio, $1050{ }^{\circ} \mathrm{C}$ baking temperature & $\mathrm{KBS} 201050$ \\
Karapınar Region Black-Colored Slag (KBS), $30 \%$ mixing ratio, $1050{ }^{\circ} \mathrm{C}$ baking temperature & $\mathrm{KBS} 301050$ \\
\hline
\end{tabular}

Table 5 Results of experiments conducted on samples

\begin{tabular}{|c|c|c|c|c|c|c|c|c|}
\hline \multirow{2}{*}{ Sample name } & \multirow{2}{*}{$\begin{array}{l}\text { Net dry } \\
\text { density }(\mathrm{kg} / \\
\left.\mathrm{m}^{3}\right)\end{array}$} & \multirow[t]{2}{*}{$\begin{array}{l}\text { True density } \\
{\left[\rho_{r}\left(\mathrm{~kg} / \mathrm{m}^{3}\right)\right]}\end{array}$} & \multicolumn{2}{|c|}{$\begin{array}{l}\text { Water absorption under normal } \\
\text { conditions }\end{array}$} & \multirow{2}{*}{$\begin{array}{l}\text { Apparent } \\
\text { porosity } \\
(\%)\end{array}$} & \multirow{2}{*}{$\begin{array}{l}\text { Compact- } \\
\text { ness ratio } \\
(\%)\end{array}$} & \multirow[t]{2}{*}{$\begin{array}{l}\text { Porosity ratio } \\
\text { (\%) }\end{array}$} & \multirow{2}{*}{$\begin{array}{l}\text { Compressive } \\
\text { strength [Avr. (N/ } \\
\left.\mathrm{mm}^{2}\right) \text { ] }\end{array}$} \\
\hline & & & $\begin{array}{l}\text { Water absorp- } \\
\text { tion by mass } \\
{\left[W_{m}(\%)\right]}\end{array}$ & $\begin{array}{l}\text { Water absorp- } \\
\text { tion by volume } \\
{\left[W_{v}(\%)\right]}\end{array}$ & & & & \\
\hline SVT 30930 & 1358 & 3303 & 35.13 & 48.05 & 47.78 & 41.21 & 58.79 & 10.8 \\
\hline SVT 301050 & 1393 & 3223 & 32.35 & 46.23 & 44.97 & 43.17 & 56.83 & 10.4 \\
\hline CT 101000 & 1735 & 3611 & 16.95 & 30.97 & 29.49 & 48.20 & 51.80 & 9.6 \\
\hline СТ 101050 & 1971 & 3463 & 11.39 & 23.01 & 22.44 & 56.94 & 43.06 & 9.48 \\
\hline KRS 20930 & 1424 & 3368 & 33.12 & 48.12 & 47.03 & 42.14 & 57.86 & 8.08 \\
\hline KRS 301050 & 1510 & 3244 & 29.17 & 45.24 & 44.05 & 46.60 & 53.40 & 9.03 \\
\hline KBS 201050 & 1670 & 3427 & 20.75 & 35.62 & 34.65 & 48.69 & 51.31 & 16.41 \\
\hline KBS 301050 & 1508 & 3547 & 29.51 & 45.26 & 44.56 & 42.54 & 57.46 & 13.11 \\
\hline
\end{tabular}




\subsubsection{Experiment results for resistance to frost action}

As a result of the frost action, observations were made about how damage occurred in the samples or that they completed the process without any signs of damage. Accordingly:

In the samples named "SVT 30 930", very slight conchoidal exfoliation was observed at the end of the 3rd cycle. During the 5th cycle of the "SVT 30930 D1" sample, it was observed that there were small cracks on the surface. The same sample started to be damaged in the form of large piece breaks during the 6 th cycle and was completely damaged in the 16th cycle (Fig. 1). Although the "SVT 30 930 D2" sample did not show any signs of damage, sudden large piece breaks were observed during the 9th cycle. The type of damage continued in the same form, and it dispersed completely in the 17th cycle. The sample named "SVT 30930 D3" showed signs of damage with small piece breaks during the 12th cycle, the damage type in the 15th cycle turned into a large piece break, and it dispersed completely at the end of the 17 th cycle.

It can be said that the samples named "SVT 30 1050" were generally resistant to the frost-decomposition process. Therefore, two of the three samples were not damaged. The only product in which damage was observed in this group was the sample named "SVT 301050 D3". In this sample, very light conchoidal exfoliation started in the 20th cycle of the experiment process, and small piece breaks were observed in the 21 st cycle (Fig. 2a). Furthermore, they turned into large piece breaks in the 22nd cycle and continued until the last cycle of the process (Fig. 2b).

It was observed that the samples named "CT 101000 " did not suffer from any damage during the frost-decomposition process (Fig. 3a, b).

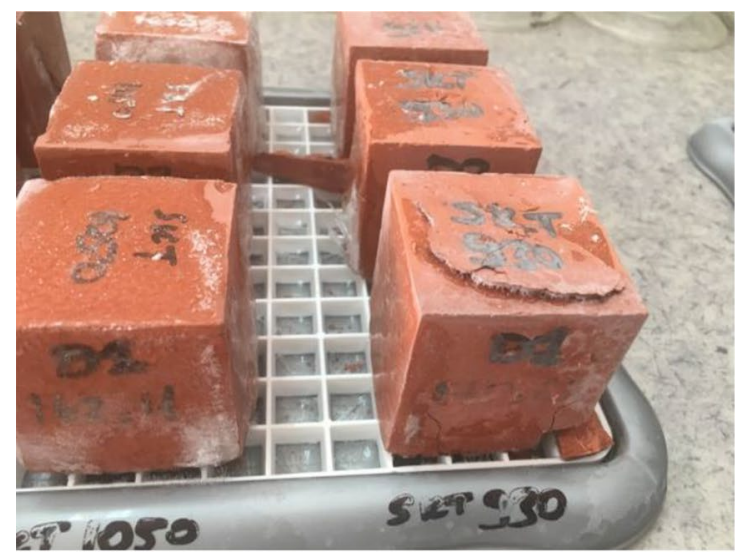

a Major damage formation in the sample named "SVT 30930 D1"
The samples named "CT 10 1050" were found to be unaffected in the experiment for resistance to frost action from the beginning to the last cycle (Fig. 4a, b).

The samples in the "KRS 20 930" group were observed to be the fastest damaged samples in this experiment period (Fig. 5a, b). The damage started in the "KRS 20930 D1" sample in the form of a small piece rupture during the 6th cycle, which grew a little more in the 7th period. Intense damage caused the complete dispersion of the sample during the 8th cycle. In the sample named "KRS 20 930 D2", a dense capillary crack was observed at the end of the 4th cycle. Capillary cracks grew enough to cause small pieces to break in the 5th cycle. At the end of the 6 th cycle, the sizes and amount of pieces increased, and, in the 8th cycle, the sample dispersed completely. Within the scope of this experiment, the sample that dispersed in the shortest time was "KRS 20930 D3". In this sample, a small number of capillary cracks were observed in the 4 th cycle. The number of these cracks increased in the 5 th cycle. In the 6th cycle, sudden breaks were observed, and the sample broke in the 7 th cycle.

In the samples named "KRS 30 1050", the first damage caused by frost-decomposition was observed in the 15th cycle. If the frost-decomposition effect on this group of samples was examined separately, the first sign of damage in the "KRS $301050 \mathrm{D} 1$ " sample was observed as small flakes in the 18th cycle. During the 21 st cycle, small pieces started to break, and the process ended in this way. In the "KRS 301050 D2" sample, a small part broke during the 20th cycle. The damage type in this sample did not change until the end of the experiment (Fig. 6a). In this group, the sample named "KRS 301050 D3" was the sample most clearly affected by frost actions. In this sample, the damage that started with the break of a small part at the end

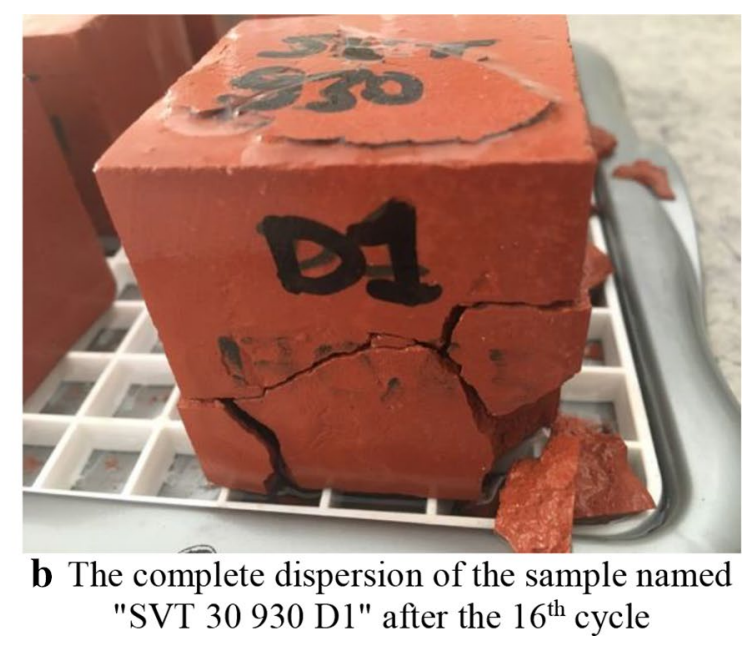

Fig. 1 Observation of damage in various cycles in the sample named "SVT 30930 D1". a Major damage formation in the sample named "SVT 30930 D1". b The complete dispersion of the sample named "SVT 30930 D1" after the 16th cycle 


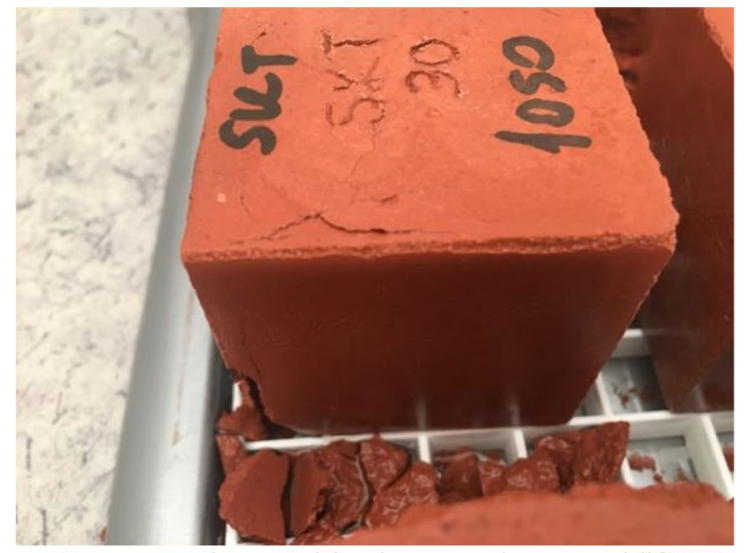

a Damage observed in the sample named "SVT

301050 D3" after the $21^{\text {st }}$ cycle

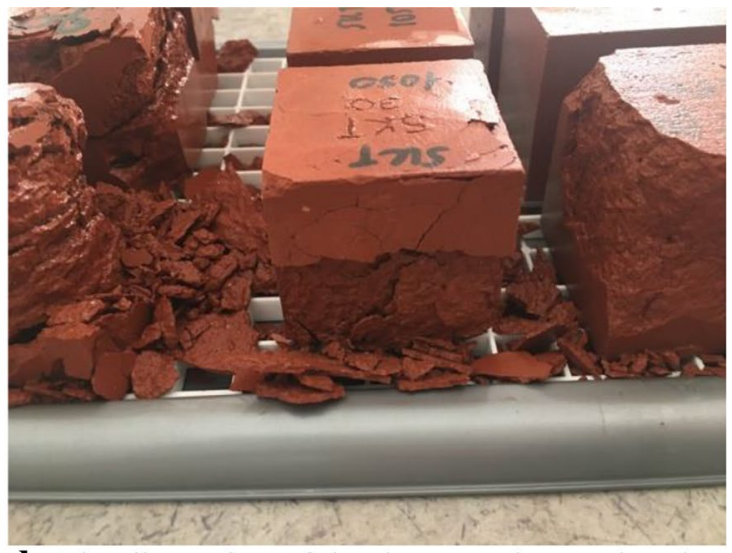

b The dimension of the damage observed at the end of the experiment in the sample named "SVT 301050 D3"

Fig. 2 The appearance of the damage in the sample named "SVT 301050 D3". a Damage observed in the sample named "SVT 301050 D3" after the 21 st cycle. b The dimension of the damage observed at the end of the experiment in the sample named "SVT 301050 D3"

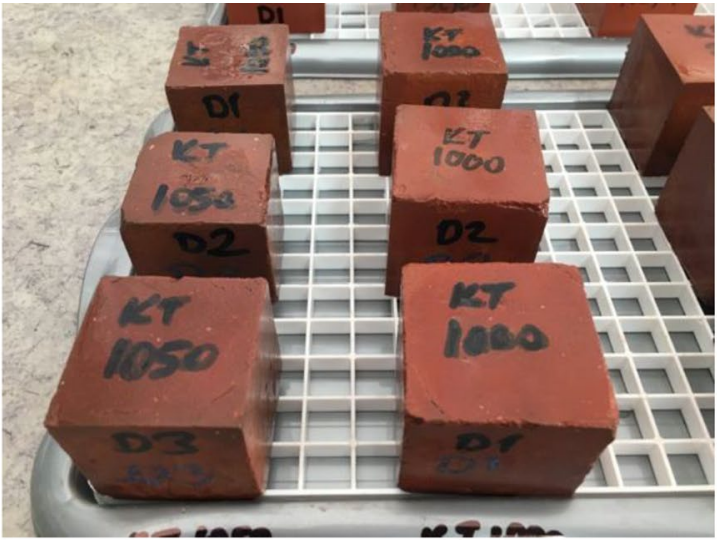

a The appearance of "CT 101050 " samples at the beginning of the experiment

Fig. 3 The appearance of "CT 10 1000" samples that were not affected by the experiment process at the beginning and end of the frost-decomposition experiment. a The appearance of " $\mathrm{CT} 10$

of the 15th cycle turned into a large break during the 17th cycle. Thus, it continued to break, as mentioned above, until the end of the experiment process (Fig. 6b).

The samples named "KBS 20 1050" were not affected by the frost-decomposition process that caused damage (Fig. 7a, b).

In the samples named "KBS 30 1050", a small number of conchoidal exfoliation was observed at the beginning of the experiment. Significant damage in this group of samples was found only in the sample named "KBS 30 1050 D1". The shape of the damage, which started with a capillary crack and small piece break, turned into a large

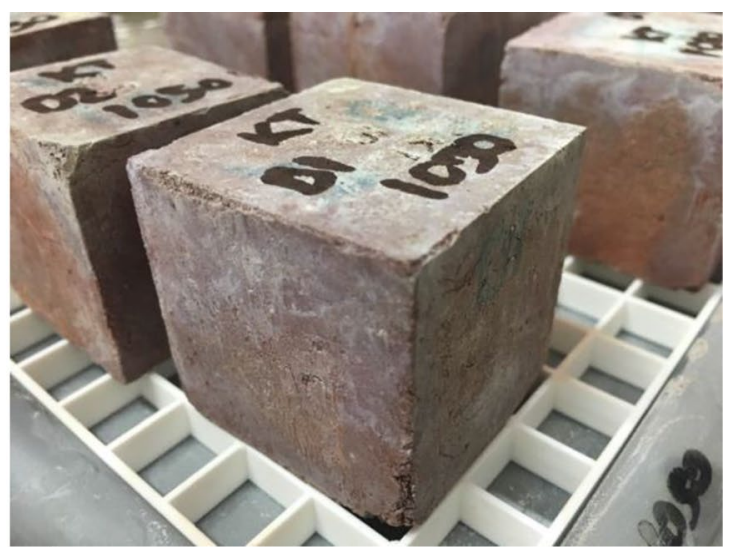

b The appearance of "CT 10 1050" samples which were turned into oven-dried at the end of the experiment

1000 " samples at the beginning of the experiment. $\mathbf{b}$ The appearance of "CT 101000 " samples which were turned into oven-dried at the end of the experiment

piece break at the end of the 22nd cycle (Fig. 8a). In other samples, either no damage or a small number of capillary cracks were observed (Fig. 8b).

The results of the frost loss calculation in the samples after the frost-decomposition process are given in Table 6 .

Many samples yielded positive results for frost action resistance. However, it is observed that the optimum mixture type that reached the highest resistance against frost action was the one having $10 \%$ of pyroclastic rock added to red mud and baked at $1050^{\circ} \mathrm{C}(\mathrm{CT} 10$ 1050). Moreover, having the least amount of the pyroclastic rock addition of $10 \%$ to red mud is a positive factor for this type. From

\section{SN Applied Sciences}




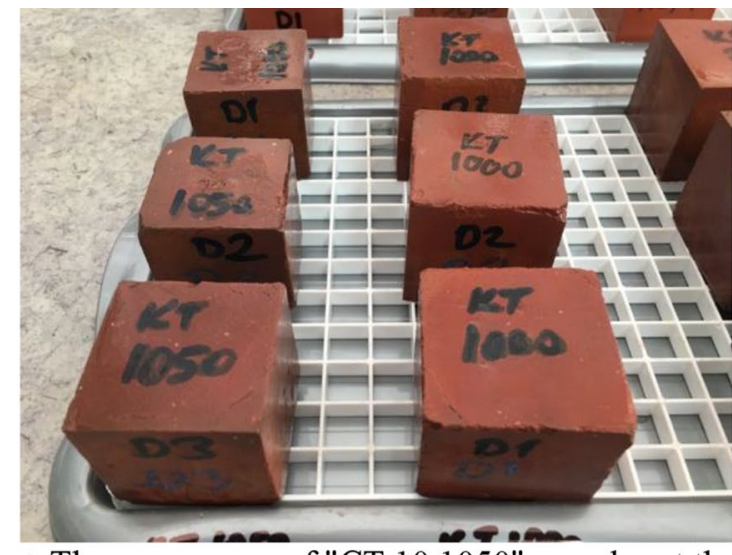

a The appearance of "CT 101050 " samples at the beginning of the experiment

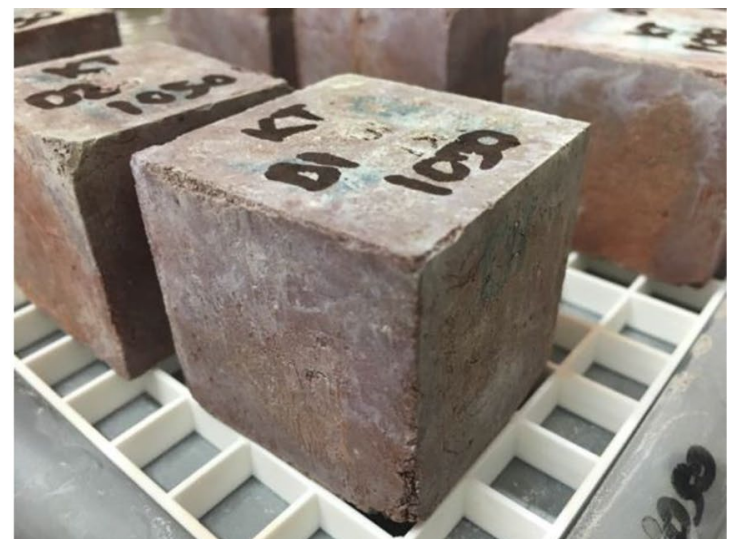

b The appearance of "CT 101050 " samples which were turned into oven-dried at the end of the experiment
Fig. 4 The appearance of "CT 10 1050" samples that were not affected by the experiment process at the beginning and end of the frost-decomposition experiment. a The appearance of " $\mathrm{CT} 10$
1050 " samples at the beginning of the experiment. b The appearance of "CT 10 1050" samples which were turned into oven-dried at the end of the experiment

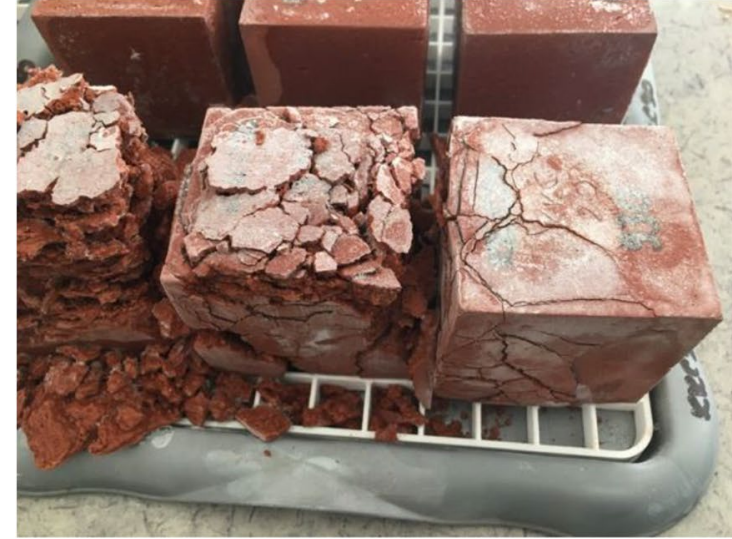

a The appearance of the samples named "KRS $20930^{\text {" after the }} 6^{\text {th }}$ cycle of the frost action process

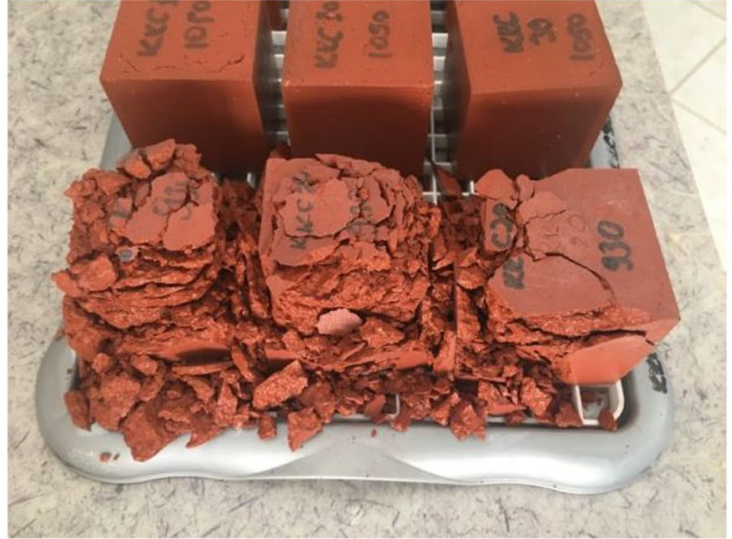

b The appearance of the samples named "KRS 20930 " at the end of the $8^{\text {th }}$ cycle

Fig. 5 The appearance of damage in the samples named "KRS 20 930". a The appearance of the samples named "KRS 20 930" after the 6th cycle of the frost action process. b The appearance of the samples named "KRS 20 930" at the end of the 8th cycle

the point of different pyroclastic material, the KBS 201050 mixture type showed positive results. Alternative optimum mixture proportions according to the pyroclastic rock addition can be observed in Table 6 .

According to the results of frost loss, the samples named SVT 30930 and KRS 20930 could not sufficiently resist to frost actions. It would be sufficient to compare this result with the frost loss results of other sample types that were related to baking temperature.

The compressive strength experiment was performed on samples that did not disperse at the end of the frost action process. Accordingly, the results of the compressive strength experiment performed under normal conditions with the end of frost compressive strength are given in Table 7.

The average compressive strength values under normal conditions and the average compressive strength values at the end of the frost-decomposition process gave values close to each other, and it was observed that the samples that remained intact were not affected by frost actions. Only the samples named "KRS 301050 " did not give this result. It was determined that the compressive strength of these samples, of which normal compressive strength was $9 \mathrm{~N} / \mathrm{mm}^{2}$ on average, decreased to $61 \mathrm{~N} / \mathrm{mm}^{2}$ at the 


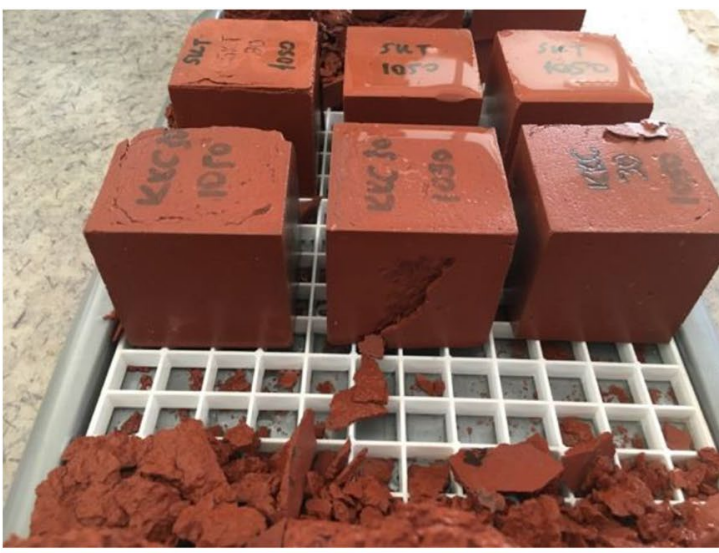

a The appearance of the samples named "KRS 301050 " after the $22^{\text {nd }}$ cycle decomposition

Fig. 6 The appearance of the samples named "KRS 30 1050" in the frost-decomposition process. a The appearance of the samples named "KRS 301050 " after the 22nd cycle decomposition. b The

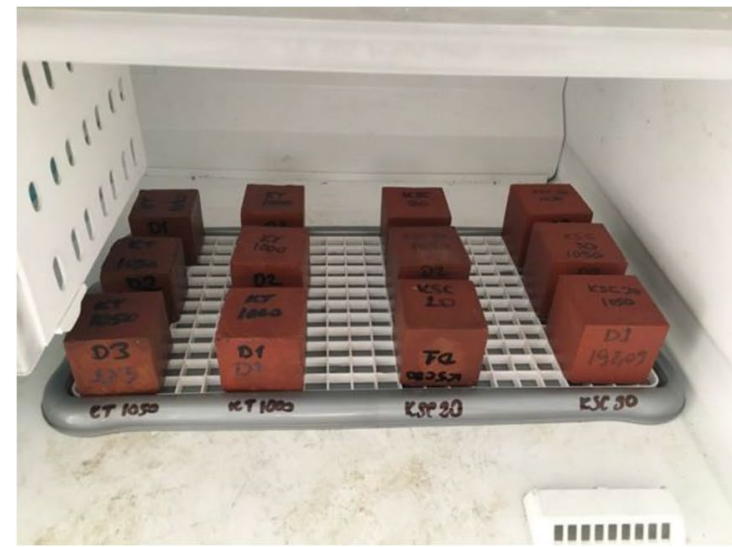

a The appearance of the samples named "KBS 201050 " at the beginning of the frost action process

Fig. 7 The appearance of the samples named "KBS 20 1050" in the frost-decomposition process. a The appearance of the samples named "KBS 201050 " at the beginning of the frost action process. $\mathbf{b}$

end of the experiment, and there might be damage that did not reflect on the outer appearance but reduced the compressive strength in the inner parts.

According to the saturation degree of the samples, it is stated in the literature that it is possible to predict frost and decomposition without the experiment process. Accordingly, in the study conducted by Koçu [48], it is stated as follows: "It can be stated that there is a relation between the degree of saturation and frost resistance. When water freezes, an increase of $9 \%$ is observed in

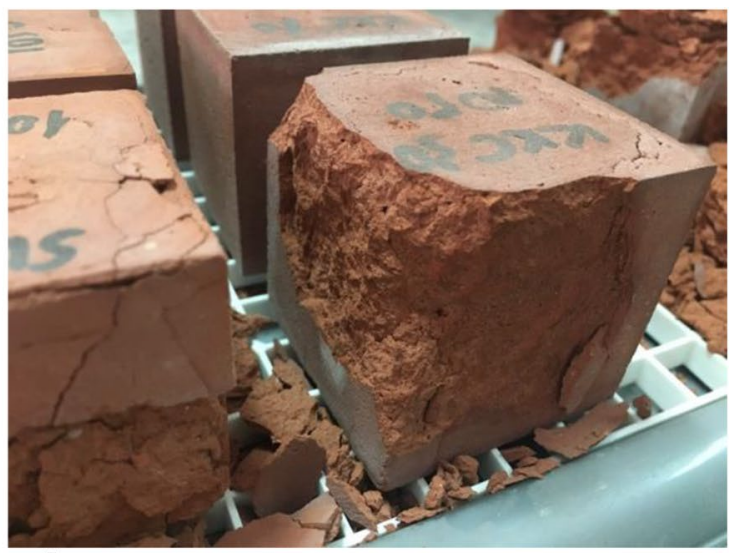

b The oven-dried appearance of the sample named "KRS 301050 D3" at the end of the experiment

oven-dried appearance of the sample named "KRS 301050 D3" at the end of the experiment

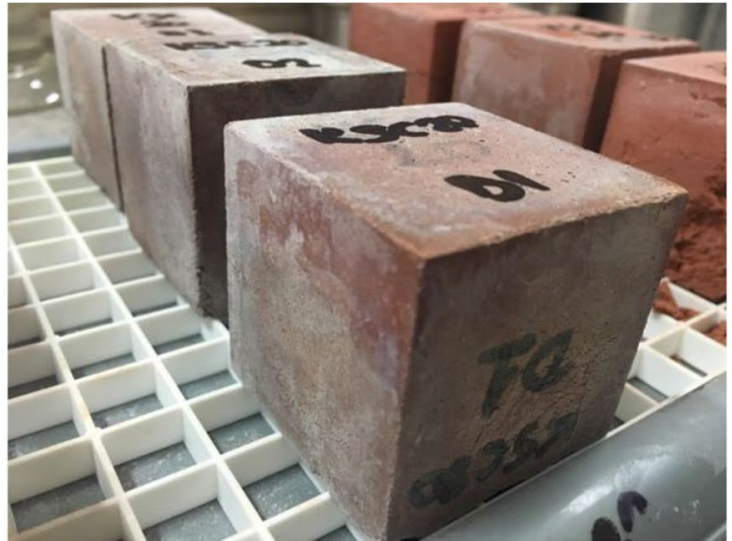

b The oven-dried appearance of the sample named "KBS 201050 " at the end of the experiment

The oven-dried appearance of the sample named "KBS 20 1050" at the end of the experiment

its volume. If the cavities of the material are filled with water, the water cannot find a gap to expand, and the material is broken down by the ice pressure. When the material is filled with water at the rate of $80 \%$ at most, the ice pressure does not cause the material to deteriorate as there is enough space during the transition to ice. In general, the saturation degree of the material is $80 \%$ or less, which gives the result that it will be resistant to the frost. The degree of saturation is calculated by proportioning the water absorption value to porosity." 


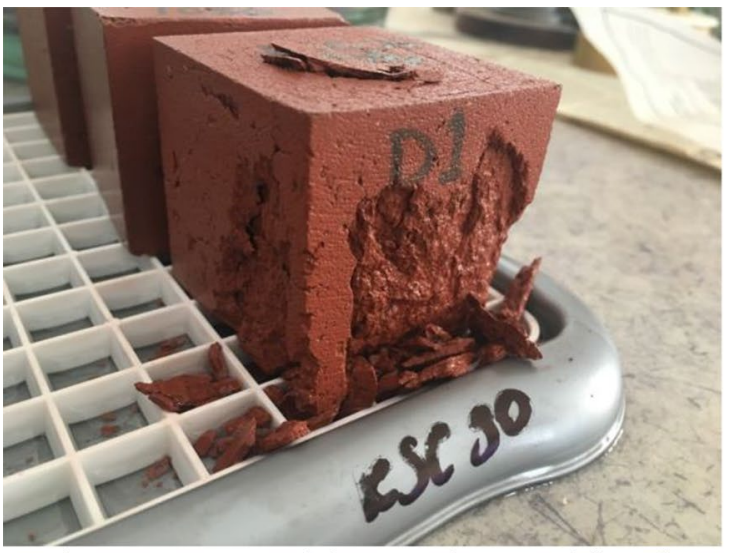

a The appearance of the sample named "KBS 30 $1050 "$ at the end of the process

Fig. 8 The appearance of the samples named "KBS 301050 " at the end of the frost-decomposition process. a The appearance of the sample named "KBS 301050 " at the end of the process. $\mathbf{b}$ The

Table 6 Frost loss values

\begin{tabular}{ll}
\hline Sample name & Frost loss (\%) \\
\hline SVT 30930 & 71 \\
SVT 301050 & 2.2 \\
CT 10 1000 & 0.3 \\
CT 10 1050 & 0.07 \\
KRS 20 930 & 100 \\
KRS 30 1050 & 3.07 \\
KBS 20 1050 & 0.15 \\
KBS 30 1050 & 3.44 \\
\hline
\end{tabular}

Table 7 Normal and end-frost compressive strength values of samples

\begin{tabular}{lll}
\hline Sample name & $\begin{array}{l}\text { Normal compres- } \\
\text { sive strength }\end{array}$ & $\begin{array}{l}\text { Compressive strength at } \\
\text { the end of the frost action } \\
\text { process }\end{array}$ \\
\hline SVT 30930 & 10.8 & 0 (dispersed sample) \\
SVT 301050 & 10.4 & 9.6 \\
CT 101000 & 9.6 & 10.8 \\
CT 101050 & 9.5 & 11 \\
KRS 20 930 & 8.1 & 0 (dispersed sample) \\
KRS 301050 & 9 & 6.1 \\
KBS 201050 & 16.4 & 15.6 \\
KBS 301050 & 13.1 & 13.6 \\
\hline
\end{tabular}

Accordingly, the saturation degrees were determined for the samples and given in Table 8.

In terms of the relation mentioned above, the samples named "KRS 20 930", "KRS 30 1050", and "SVT 30 930", "SVT 30 1050" are likely to be damaged during the

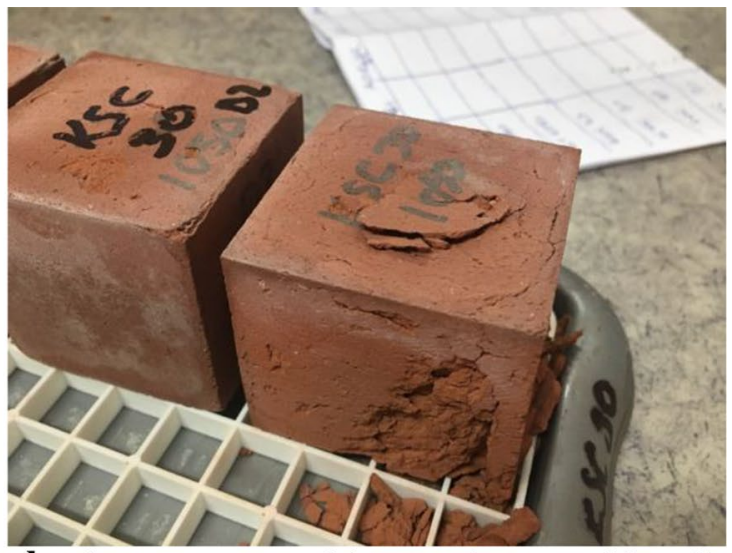

b The appearance of the samples named "KBS $301050^{\prime \prime}$ at the end of the frost-decomposition process

appearance of the samples named "KBS 301050 " at the end of the frost-decomposition process

Table 8 Saturation degrees of the samples

\begin{tabular}{lll}
\hline Sample name & $\begin{array}{l}\text { Saturation degree by } \\
\text { mass (\%) }\end{array}$ & $\begin{array}{l}\text { Saturation } \\
\text { degree by vol- } \\
\text { ume (\%) }\end{array}$ \\
\hline SVT 30930 & 59.76 & 81.73 \\
SVT 301050 & 56.92 & 81.34 \\
CT 10 1000 & 32.72 & 59.78 \\
CT 10 1050 & 26.44 & 53.42 \\
KRS 20 930 & 57.25 & 83.16 \\
KRS 30 1050 & 55.00 & 84.73 \\
KBS 20 1050 & 40.43 & 69.42 \\
KBS 30 1050 & 51.35 & 78.77 \\
\hline
\end{tabular}

frost-decomposition process according to their saturation degrees by volume. With this prediction, it was determined that the probability of damage occurred partially at the end of the experiment, except for the SVT 301050 sample. With the experimental method, it was revealed that it was possible to predict the possibility of damage against frostdecomposition in general, but it did not give exact results.

Although there is no appropriate literature to make a direct comparison about the subject of the study, there are many studies on the frost action resistance of brick materials used in masonry. In some of these studies, there are views expressing that the freeze-thaw experiment processes conducted according to especially the American (ASTM International) and Canada (CSA) standards will not reflect the truth $[49,50]$. In these studies, it is stated that environmental conditions will be different and other factors can play a role. From this point of view, it can be 
said that the experiment process is effective beyond the real conditions. In fact, water absorption is observed on six surfaces of a cube experiment sample, and all surfaces are affected by frost actions. However, under natural conditions, water absorption that is effective on frost occurs on one surface of the material, unlike experiment samples, and the pore structure of the material and other environmental conditions (wind, etc.) also become effective. From this point of view, there is a kernel of truth in these studies. Nevertheless, the ambient conditions selected in the experimental process should be accepted as the toughest conditions that the material will face. Therefore, it is certain that a material with durable results under experimental conditions will not suffer damage under normal environmental conditions. Still, it is useful to know the other factors along with the experimental process. For example, it can be thought that a material with a high potential of water absorption will be affected by frost actions. However, the subject cannot be interpreted in this way. If the pore structure of the material will allow the volume increase in frost, it means that the material will not be affected by frost actions. Another effective factor is the $\mathrm{CaCO}_{3}$ amount in raw materials. There are views expressing the idea that the less this amount is, the higher the resistance to frost action will be [51]. According to the XRF analysis, the $\mathrm{CaO}$ traces of the raw materials used in the study are not in the amount that affects the process. According to the results of the comparison in the literature, the information "it is durable to frost actions" obtained as a result of the experiments is certain and accurate. The other adverse results can be interpreted by considering different factors.

\section{Conclusion and recommendations}

The observations of the micronized pyroclastic rocks added to red mud in terms of resistance to frost actions are as follows:

- It was concluded that baked building materials, such as brick, clinker, ceramic, could be produced with the optimum mixture type and could be used within the building exterior wall without being affected by different climatic conditions.

- The pyroclastic addition created gaps in the baked building material. Accordingly, the water absorption amounts of the samples were at high rates. This result affected the resistance of the samples to frost action.

- In terms of its physical properties, it was found that it had a hollow structure and it was light. Therefore, it could be a breathing building material used in the outer shell design.

SN Applied Sciences

A SPRINGER NATURE journat
In general, it was concluded that it could be used as a modern building material with some types of the mixture, that it was suitable for both compressive strengths, resistant to frost actions and other external effects, light, breathing, and it could help to regulate indoor comfort conditions.

In the study, some additional research can be conducted for samples that could not withstand frost actions. For example, alternative tests can be carried out to reduce porosity ratio, glazing, etc., and studies can be conducted to use materials obtained from these regions.

Acknowledgements This study was prepared by referring to the doctoral dissertation written by Mustafa DERELI in May 2019 and entitled "Analysis of the effects of micronized pyroclastic rock addition to red mud directed at the sustainable building material production".

\section{Compliance with ethical standards}

Conflict of interest All authors declare that they have no conflict of interest.

\section{References}

1. USGS (2020) Mineral commodity summaries 2020: U.S. Geological Survey. U.S. Government Publishing Office. https://doi. org/ $10.3133 / \mathrm{mcs} 2020$

2. Power G, Grafe M, Klauber C (2011) Bauxite residue issues: I. Current management, disposal and storage practices. Hydrometallurgy 108(1-2):33-45. https://doi.org/10.1016/j.hydro met.2011.02.006

3. Mayes WM, Burke IT, Gomes HI, Anton ÁD, Molnár M, Feigl V, Ujaczki É (2016) Advances in understanding environmental risks of red mud after the Ajka Spill, Hungary. J Sustain Metall 2(4):332-343. https://doi.org/10.1007/s40831-016-0050-z

4. Winkler D, Bidlo A, Bolodar-Varga B, Erdo A, Horvath A (2018) Long-term ecological effects of the red mud disaster in Hungary: regeneration of red mud flooded areas in a contaminated industrial region. Sci Total Environ 644:1292-1303. https://doi. org/10.1016/j.scitotenv.2018.07.059

5. Piga L, Pochetti F, Stoppa $L$ (1993) Recovering metals from red mud generated during alumina production. JOM-US 45(11):5459. https://doi.org/10.1007/bf03222490

6. Mahinroosta M, Karimi Z, Allahverdi A (2020) Recycling of red mud for value-added applications: a comprehensive review. Encycl Renew Sustain Mater 2:561-582. https://doi.org/10.1016/ B978-0-12-803581-8.11474-2

7. Kavas T (2006) Use of boron waste as a fluxing agent in production of red mud brick. Build Environ 41(12):1779-1783. https:// doi.org/10.1016/j.buildenv.2005.07.019

8. Yang JK, Xiao B (2008) Development of unsintered construction materials from red mud wastes produced in the sintering alumina process. Constr Build Mater 22(12):2299-2307. https:// doi.org/10.1016/j.conbuildmat.2007.10.005

9. Xu YT, Yang B, Liu XM, Gao S, Li DS, Mukiza E, Li HJ (2019) Investigation of the medium calcium based non-burnt brick made by red mud and fly ash: durability and hydration characteristics. Int J Min Met Mater 26(8):983-991. https://doi.org/10.1007/s1261 3-019-1814-9 
10. Yang JK, Zhang DD, Hou J, He BP, Xiao B (2008) Preparation of glass-ceramics from red mud in the aluminium industries. Ceram Int 34(1):125-130. https://doi.org/10.1016/j.ceram int.2006.08.013

11. Xu XH, Song J, Li Y, Wu JF, Liu X, Zhang C (2019) The microstructure and properties of ceramic tiles from solid wastes of Bayer red muds. Constr Build Mater 212:266-274. https://doi. org/10.1016/j.conbuildmat.2019.03.280

12. Tsakiridis PE, Agatzini-Leonardou S, Oustadakis P (2004) Red mud addition in the raw meal for the production of Portland cement clinker. J Hazard Mater 116(1-2):103-110. https://doi. org/10.1016/j.jhazmat.2004.08.002

13. Liu XM, Zhang N (2011) Utilization of red mud in cement production: a review. Waste Manag Res 29(10):1053-1063. https:// doi.org/10.1177/0734242×11407653

14. Yalcin N, Sevinc V (2000) Utilization of bauxite waste in ceramic glazes. Ceram Int 26(5):485-493. https://doi.org/10.1016/S0272 -8842(99)00083-8

15. Kumar S, Kumar R, Bandopadhyay A (2006) Innovative methodologies for the utilisation of wastes from metallurgical and allied industries. Resour Conserv Recycl 48(4):301-314. https:// doi.org/10.1016/j.resconrec.2006.03.003

16. Kumar A, Kumar S (2013) Development of paving blocks from synergistic use of red mud and fly ash using geopolymerization. Constr Build Mater 38:865-871. https://doi.org/10.1016/j.conbu ildmat.2012.09.013

17. Ye N, Yang JK, Liang S, Hu Y, Hu JP, Xiao B, Huang QF (2016) Synthesis and strength optimization of one-part geopolymer based on red mud. Constr Build Mater 111:317-325. https://doi. org/10.1016/j.conbuildmat.2016.02.099

18. Hajjaji W, Andrejkovicova S, Zanelli C, Alshaaer M, Dondi M, Labrincha JA, Rocha F (2013) Composition and technological properties of geopolymers based on metakaolin and red mud. Mater Des 52:648-654. https://doi.org/10.1016/j.matde s.2013.05.058

19. Lin HF, Abubakar A, Li CM, Li YJ, Wang C, Gao SQ, Liu ZE, Yu J (2020) Development of red mud coated catalytic filter for $\mathrm{NO}_{x}$ removal in the high temperature range of $300-450^{\circ} \mathrm{C}$. Catal Lett 150(3):702-712. https://doi.org/10.1007/s10562-019-02953-x

20. Liu F, Yang L, Wu X, Zhang X, Liu Y (2020) Bauxite waste with low $\mathrm{Fe}_{2} \mathrm{O}_{3}$ and high $\mathrm{Na}$ concentration as a promising oxygen carrier in chemical looping combustion. Int J Energ Res. https://doi. org/10.1002/er.5167

21. Shi WL, Ren HJ, Huang XL, Li MY, Tang YB, Guo F (2020) Low cost red mud modified graphitic carbon nitride for the removal of organic pollutants in wastewater by the synergistic effect of adsorption and photocatalysis. Sep Purif Technol. https://doi. org/10.1016/j.seppur.2019.116477

22. Hossain KMA (2005) Volcanic ash and pumice as cement additives: pozzolanic, alkali-silica reaction and autoclave expansion characteristics. Cem Concr Res 35(6):1141-1144. https://doi. org/10.1016/j.cemconres.2004.09.025

23. Kupwade-Patil K, Palkovic SD, Bumajdad A, Soriano C, Buyukozturk O (2018) Use of silica fume and natural volcanic ash as a replacement to Portland cement: micro and pore structural investigation using NMR, XRD, F'TIR and X-ray microtomography. Constr Build Mater 158:574-590. https://doi.org/10.1016/j. conbuildmat.2017.09.165

24. Labbaci Y, Abdelaziz Y, Mekkaoui A, Alouani A, Labbaci B (2017) The use of the volcanic powders as supplementary cementitious materials for environmental-friendly durable concrete. Constr Build Mater 133:468-481. https://doi.org/10.1016/j.conbuildma t.2016.12.088

25. Demirdag S, Ugur I, Sarac S (2008) The effects of cement/fly ash ratios on the volcanic slag aggregate lightweight concrete masonry units. Constr Build Mater 22(8):1730-1735. https://doi. org/10.1016/j.conbuildmat.2007.05.011

26. Serra MF, Conconi MS, Suarez G, Aglietti EF, Rendtorff NM (2015) Volcanic ash as flux in clay based triaxial ceramic materials, effect of the firing temperature in phases and mechanical properties. Ceram Int 41(5):6169-6177. https://doi.org/10.1016/j. ceramint.2014.12.123

27. Hepper EN, Buschiazzo DE, Hevia GG, Urioste A, Anton L (2006) Clay mineralogy, cation exchange capacity and specific surface area of loess soils with different volcanic ash contents. Geoderma 135:216-223. https://doi.org/10.1016/j.geode rma.2005.12.005

28. Kılıç Y (2013) The investigation of calcined red mud effects on pozzolanic activity and colouring, mineralogical and physical properties of concrete. Yıldız Technical University, İstanbul

29. TS_EN_15309 (2008) Characterization of waste and soil-determination of elemental composition by X-ray fluorescence. vol EN 15309

30. TS_EN_ISO_17892-3 (2016) Geotechnical investigation and testing-Laboratory testing of soil-part 3: determination of particle density. vol EN ISO 17892-3

31. TS_1900-1 (2006) Methods of testing soils for civil engineering purposes in the laboratory. vol TS 1900-1

32. ASTM_C109 (2013) Standard test method for compressive strength of hydraulic cement mortars (using 50-mm cube specimens). vol C109M-13. ASTM International, West Conshohocken, PA

33. TS_EN_772-13 (2002) Methods of test for masonry units-Part 13: determination of net and gross dry density of masonry units (except for natural stone). vol TS EN 772-13

34. TS_EN_1936 (2010) Natural stone test methods-determination of real density and apparent density and of total and open porosity. vol TS EN 1936

35. TS_EN_771-1 (2016) Specification for masonry units-part 1 clay masonry units. vol TS EN 771-1 + A1

36. TS_699 (2009) Natural building stones-methods of inspection and laboratory testing. vol TS 699

37. TS_EN_772-1 (2015) Methods of test for masonry units - part 1: determination of compressive strength. vol TS EN 772-1 + A1

38. ASTM_C67-11 (2011) Standard test methods for sampling and testing brick and structural clay tile. ASTM International, West Conshohocken, PA. https://doi.org/10.1520/c0067-11

39. TS_EN_539-2 (2017) Clay roofing tiles for discontinuous layingdetermination of physical characteristics-part 2: test for frost resistance. vol TS EN 539-2

40. Dereli M (2004) The solutions to exterior plaster damages in houses and alternative plaster trials (Konya Model). Institute of Natural and Applied Sciences, Selcuk University, Konya

41. Malayoğlu U, Akar A (1995) Classification and usage areas of clays the criteria sought in the determination. Paper presented at the Industrial raw materials symposium, İzmir, Turkey, September 1995

42. American_Petroleum_Institute (2010) Specification for drilling fluids - specifications and testing. Bentonite, vol API 13A

43. TS_EN_ISO_13500 (2010) Petroleum and natural gas industries_drilling fluid materials-specifications and tests. TS EN ISO 13500

44. TS_EN_1536 (2010) Execution of special geotechnical workbored piles. vol TS EN $1536+\mathrm{A} 1$

45. TS_EN_1538 (2011) Execution of special geotechnical workdiaphragm walls. vol TS EN 1538:2010

46. TS_704 (1979) Clay bricks (wall tile) (withdrawn standard). vol TS 704

47. Özdemir A (2002) Capillary water absorption potentials of some building materials. Geol Eng 26:19-32 
48. Koçu N (1997) A research on evaluation of volcanic tuffs around Konya as building materials and determination of their properties. Institute of Natural and Applied Sciences, İstanbul Technical University

49. Vračević $M$, Ranogajec J, Vučetić S, Netinger I (2014) Evaluation of brick resistance to freeze/thaw cycles according to indirect procedures. Građevinar 66(3):197-209. https://doi.org/10.14256 /JCE.956.2013

50. Straube J, Mensinga P, Schumacher C (2010) Assessing the freeze-thaw resistance of clay brick for interior insulation retrofit projects. Paper presented at the thermal performance of the exterior envelopes of whole buildings-11th international conference, Clearwater Beach, Florida

51. Malaiškienè J, Mačiulaitis R (2013) Frost resistant ceramics produced from local raw materials and wastes. Proc Eng 57:739745. https://doi.org/10.1016/j.proeng.2013.04.093

Publisher's Note Springer Nature remains neutral with regard to jurisdictional claims in published maps and institutional affiliations. 